\title{
HYPERTENSION, BODY MASS INDEX, AND THEIR ASSOCIATIONS WITH TYPE 2 DIABETES MELLITUS IN DELI SERDANG, NORTH SUMATERA
}

\author{
Suaidah, Albiner Siagian, Fazidah Aguslina \\ Universitas Sumatera Utara
}

\begin{abstract}
Background: Diabetes mellitus (DM) is a major public health problem worldwide. Current global estimates indicate that this condition affects 415 million people and is set to escalate to 642 million by the year 2040. Type 2 DM is a metabolic disease that occurs due to abnormalities in insulin secretion. This study aimed to analyze the associations of hypertension and body mass index with type 2 DM in Deli Serdang, North Sumatera.

Subjects and Methods: This was a case-control study conducted in Deli Serdang, North Sumatera. A sample of 92 patients was selected for this study consisting 46 patients with type $2 \mathrm{DM}$ and 46 patients without type $2 \mathrm{DM}$. The dependent variable was type $2 \mathrm{DM}$. The independent variables were hypertension and body mass index. Type $2 \mathrm{DM}$ and hypertension data were obtained from the medical record. The other data were collected by questionnaire. The data were analyzed by multiple logistic regression.

Results: Type $2 \mathrm{DM}$ was associated with hypertension $(\mathrm{OR}=3.56 ; \mathrm{p}=0.004)$ and $\mathrm{BMI} \geq 25(\mathrm{OR}=5.66 ; \mathrm{p}<0.001)$.

Conclusion: Type $2 \mathrm{DM}$ is associated with hypertension and BMI $\geq 25$.
\end{abstract}

Keywords: type 2 DM, hypertension, body mass index

Correspondence:

Suaidah. Universitas Sumatera Utara, Medan, North Sumatera.

Email: suaidahidah85@gmail.com. Mobile: +6281264350209.

The 4th International Conference on Public Health

Best Western Premier Hotel, Solo, Indonesia, August 29-30, 2018 | 83

https://doi.org/10.26911/theicph.2018.01.44 